\title{
In what ways to Confucianism and Daoism complement each other? In what ways do they oppose each other?
}

Course Hero

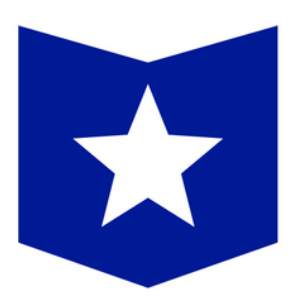

\section{Course Hero}

https://www.coursehero.com/tutors-

problems/Philosophy/27699417-In-what-ways-to-

Confucianism-and-Daoism-complement-each-other-In-what/

January 2021 


\section{This question has been answered}

\section{Question}

In what ways to Confucianism and Daoism complement each other? In what ways do they oppose each other?

\section{Answered by Expert Tutors ?}

Confucianism one of the most prominent religious philosophies in China's history. It has existed for over 2,500 years. Inner virtue, morals, and regard for the world and its ideals are concerned. Daoism is a philosophy, a religion, and a way of life which originated in what is now the eastern Chinese province of Henan in the 6th century BCE. Since then it has greatly affected China and other East Asian countries' culture and religious life.

The following are ways to Confucianism and Daoism complement each other:

- Both Confucianism and Daoism have one goal and are based on developing themselves from being citizens by accepting a greater whole to contribute to society.

- Both were invented to provide solutions to the turmoil that erupted as a consequence of the collapse of the Zhou Dynasty.

- Confucianism and Daoism also teach about family and the proper role of one in society. Confucius emphasized that you were superior to the elders, while Lao indicated that men were superior to women, because both had a kind of social hierarchy.

- These two sects both showed appreciation for what they were teaching.

- Both hold similar beliefs concerning man, culture, and the cosmos.

The following are ways to Confucianism and Daoism oppose each other:

- While Daoism emphasizes belief in nature and a natural way of coping with life, Confucianism is based on human actions as opposed to religion and belief in God.

- Nature is the main focus of Daoism; Confucianism is focused on improving society.

- Daoism was founded by Lao Tzu; Confucianism was founded by Kong Qui.

- Daoism's aim is to have a balanced life; Confucianism's goal is to establish peace in society.

- Women are held as valued members of society by Daoism; Confucianism allows women to be inferior to men.

- Daoism has holidays, ancestor day and the three-day festival of the dead on the Chinese New Year while Confucianism has holidays and Teacher Day on the first two days.

\section{Step-by-step explanation}

\section{References}

Similarities between confucianism and taoism. (2017, December 7). Retrieved December 7, 2020 ,

from https://www.knowswhy.com/similarities-between-confucianism-and-taoism/

National Geographic Society. (2020, July 7). Confucianism. Retrieved December 7, 2020, from

https://www.nationalgeographic.org/encyclopedia/confucianism/

Compare and contrast essay on taoism and confucianism. (2020, May 8). R

2020, from https://grademiners.com/blog/what-you-need-to-know-about-w contrast-confucianism-and-taoism-essay

Tang, Y. (2015). Confucianism, Buddhism, Daoism, Christianity and Chinese C 
Vuong, Q. H., Bui, Q. K., La, V. P., Vuong, T. T., Nguyen, V. H. T., Ho, M. T., ... \& Ho, M. T. (2018). Cultural additivity: behavioural insights from the interaction of Confucianism, Buddhism and Taoism in folktales. Palgrave Communications, 4(1), 1-15.

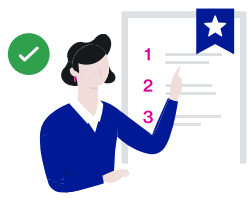

79,860 students got unstuck by Course Hero in the last week

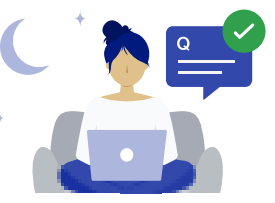

Our Expert Tutors provide step by step solutions to help you excel in your courses

\section{Related questions}

How various perspective (Philosophical, Sociological, Anthropological,...

Hello! We will be having a "Dialogue among Thinkers", a performance task...

\section{Recently asked questions}

Q1. In general terms, compare and contrast scientific attempts to explain t...
If we explore the thinking of intellectual "Giants", our goal being that you learn t...

can you answer these questions for me please. 1 - What is a significant judgment...
Provide what is being referred in each statement. 1 . It refers to the...

How is philosophy relevant with understanding the self, the self's...
(1) GERIFIED \& SECURED UERIFY SECURITY
-In-text citations. -References. Sexuality Education: Why is education on sexualit...
Do you think morality must disappear if everything we do can be explained...

\section{Company}

About Us

Scholarships

Sitemap

Standardized Tests

Education Summit

Educator Resources

\section{Help}

Contact Us

FAQ

Feedback

\section{Get Course Hero}

iOS

Android

Educators
PRIVACY FEEDBACK Powered by TRUSTe
Legal

Copyright Policy

Academic Integrity.

Our Honor Code

Privacy Policy.

Terms of Use

\section{Careers}

Leadership

Careers

Campus Rep Program

\section{Connect with Us}

rollonal ifo

Let our 24/7 Philosophy tutors help you get unstuck! Ask your first question.

I inkadin 


\section{References}

Jones V. (2017). Similarities between confucianism and taoism. Knowswhy. Retrieved December 7, 2020, from https://www.knowswhy.com/similarities-between-confucianismand-taoism/

National Geographic Society. (2020, July 7). Confucianism. Retrieved December 7, 2020, from https://www.nationalgeographic.org/encyclopedia/confucianism/

Nita J. (2020). Compare and contrast essay on taoism and confucianism. Grademiner (May 8). Retrieved December 7, 2020, from https://grademiners.com/blog/what-you-need-toknow-about-writing-a-compare-and-contrast-confucianism-and-taoism-essay

Tang Y. (2015). Confucianism, Buddhism, Daoism, Christianity and Chinese Culture. Springer.

Vuong QH, et al. (2018). Cultural additivity: behavioural insights from the interaction of Confucianism, Buddhism and Taoism in folktales. Palgrave Communications, 4(1), 143.

Vuong QH, et al. (2020). On how religions could accidentally incite lies and violence: Folktales as a cultural transmitter. Palgrave Communications, 6(1), 82. 